\title{
Potensi Air Sulingan Beberapa Bagian Tanaman Kopi sebagai Atraktan terhadap Hama Penggerek Buah Kopi (Hypothenemus hampeii Ferr.) di Laboratorium
}

\author{
Siska Rasiska ${ }^{*}$, Deni Ariyono², dan Fitri Widiantini ${ }^{1}$ \\ ${ }^{1}$ Departemen Hama dan Penyakit Tumbuhan, Fakultas Pertanian Universitas Padjadjaran \\ Jalan Raya Bandung-Sumedang KM 21. Jatinangor, Indonesia 45363. \\ ${ }^{2}$ Departemen Kimia, FMIPA Universitas Padjadjaran, \\ Jalan Raya Bandung-Sumedang KM 21. Jatinangor, Indonesia 45363. \\ Alamat korespondensi: s.rasiska@unpad.ac.id
}

\author{
ABSTRACT \\ Potency of Distilled Water of Several Parts of Coffee Plant as Attractant of Coffee Berry Borer \\ (Hypothenemus hampeii Ferr.) in Laboratory
}

Coffee berry borer (Hypothenemus hampeii Ferr.) is one of coffee plant pests, causing fruit damage up to 50 percent. One of control technicques to eliminate the adult female is the use of attractants obtained from parts of coffee plant. The aim of this research was to know the potency of distilled water of parts of coffee plant as attractant to control coffee berry borer. Research was done in the Laboratory of Entomology, Department of Plant Pests and Diseases, Faculty of Agriculture, Universitas Padjadjaran, from February to July 2015. Experiment was conducted in a Randomized Block Design. The treatments were control without distilled water (P0), coffee exocarp distilled water (P1), coffee berry distilled water (P2), coffee leaves distilled water (P3), and coffee branch distilled water (P4). Each treatment was replicated five times. The result showed that distilled water of coffee plant had a potency as attractant of coffee berry borer. Distilled water of coffee bean at the concentration of $4 \%$ had the strongest effect, attracting coffee berry borer of 8.8 female adult. The effectiveness of coffee plant distilled water in attracting coffee berry borer lasted three days.

Keyword: Distilled water, Attractant, Coffee berry borer

\begin{abstract}
ABSTRAK
Penggerek buah kopi (PBKo, Hypothenemus hampei Ferr.) merupakan hama utama tanaman kopi yang dapat menyebabkan kerusakan hingga $50 \%$. Salah satu teknik pengendalian imago betina PBKo yang dapat dilakukan adalah dengan menggunakan senyawa atraktan yang terkandung di dalam bagian tanaman kopi. Penelitian ini bertujuan untuk mengetahui potensi air sulingan bagian tanaman kopi sebagai atraktan terhadap hama PBKo. Percobaan dilakukan di Laboratorium Entomologi, Departemen Hama dan Penyakit Tumbuhan Fakultas Pertanian Universitas Padjadjaran pada bulan Februari 2015 sampai dengan Juli 2015. Metode yang digunakan adalah eksperimen dengan Rancangan Acak Kelompok dengan perlakuan yaitu tanpa pemberian air sulingan (P0); air sulingan kulit buah kopi (P1), biji kopi (P2), daun kopi (P3), dan ranting kopi (P4) dengan konsentrasi masing-masing sebesar 2\%, 4\% dan 6\%. Masing-masing perlakuan diulang sebanyak lima kali. Hasil penelitian menunjukkan air sulingan bagian tanaman kopi berpotensi sebagai atraktan terhadap hama PBKo. Rata-rata jumlah imago betina PBKo terbanyak yang tertarik yaitu pada air sulingan biji kopi pada konsentrasi $4 \%$ sebanyak 8,8 ekor betina. Masa aktif dari semua air sulingan yang berperan sebagai atraktan dalam menarik imago betina PBKo yaitu selama 3 hari.
\end{abstract}

Kata kunci: Air sulingan, Aatraktan, Penggerek buah kopi 


\section{PENDAHULUAN}

Kopi termasuk komoditas perkebunan andalan yang memiliki kontribusi besar terhadap perekonomian di Indonesia sebagai sumber devisa. Indonesia merupakan negara pengekspor kopi terbesar ketiga di dunia setelah Brazil dan Vietnam (AEKI, 2014a). Nilai ekspor kopi Indonesia tahun 2014 sekitar 5,6\% dari total ekspor kopi dunia setelah Brazil 16,07\% dan Vietnam 10,34\% (Kemendag, 2014).

Sebagian besar luas areal kopi di Indonesia diusahakan dalam skala perkebunan rakyat sebanyak 96\% dan 4\% milik perkebunan swasta dan pemerintah (Kustiari, 2007). Total luas areal pertanaman kopi tahun 2014 mencapai 1.331 .000 ha dan jumlah produksi sekitar 738.000 ton (AEKI, 2014b).

Berdasarkan data BPS (2013) peningkatan jumlah produksi kopi dalam kurun waktu 5 tahun terakhir cenderung tidak stabil. Beberapa hal yang menyebabkan produksi tidak stabil yaitu pengaruh cuaca yang tidak mendukung maupun keberadaan serangga hama yang mampu menurunkan kuantitas dan kualitas kopi yang dihasilkan.

$$
\text { Penggerek buah kopi (PBKo, }
$$

Hypothenemus hampei Ferr.) merupakan hama utama yang menyerang tanaman kopi di seluruh dunia. Pada umumnya tingkat kerusakan yang diakibatkan oleh serangan hama PBKo di Indonesia hingga mencapai 50\% (Wiryadiputra, 2012).

Kerusakan yang ditimbulkan oleh hama PBKo diantaranya buah muda berguguran dan buah matang menjadi berlubang lalu membusuk (Jaramillo et al., 2006). Pada beberapa kasus serangan hama PBKo juga dapat berlanjut hingga di tempat penyimpanan (Susilo, 2008). Kerugian yang ditimbulkan tersebut mengakibatkan kuantitas dan kualitas kopi yang dihasilkan rendah sehingga mampu menurunkan harga kopi sekitar $30-40 \%$ (Durham, 2004).

Teknik pengendalian umum yang dilakukan oleh petani masih mengandalkan penggunaan insektisida sintetik karena memiliki efek knock down yang cepat. Penggunaan insektisida sintetik secara intensif memberikan dampak negatif seperti pencemaran lingkungan, kontaminasi residu pada buah kopi dan terjadi resistensi pada beberapa jenis serangga hama (Lima et al., 2010). Pengendalian dengan mengandalkan insektisida sintetik juga tidak efektif karena hampir sebagian besar stadia perkembangan hama PBKo berada di dalam buah kopi (Damon, 2000).

Salah satu solusi pengendalian yang efektif dan ramah lingkungan dalam menekan populasi hama PBKo yaitu menggunakan senyawa atraktan beberapa bagian tanaman kopi. Ketertarikan hama PBKo terhadap air sulingan bagian tanaman kopi salah satunya disebabkan oleh kandungan asam klorogenat yang mampu menarik imago dalam meletakkan telur (Firmansyah, 2012). Kandungan asam klorogenat terdapat di semua bagian tanaman kopi sehingga berpotensi untuk dikembangkan sebagai senyawa atraktan alami.

Buah kopi mengandung sekitar 50 jenis komponen senyawa volatil organik yang mampu menarik serangga hama. Senyawa kimia volatil organik dominan yang ditemukan diantaranya spiroacetal conophthorin, frontalin dan metil 3-etil4-metil pentanoat (Jaramillo et al., 2013). Kandungan senyawa volatil organik (kairomone) pada buah kopi mampu menarik imago betina PBKo dalam mengkolonisasi buah kopi (Dufour \& Frerot, 2008). Pada umumnya kandungan senyawa volatil organik pada buah yang sudah matang lebih banyak 10 kali lipat dibandingkan buah yang masih muda (Jaramillo et al., 2013).

Penggunaan atraktan berbahan dasar ekstrak biji tanaman kopi memiliki hasil yang lebih baik dalam menarik imago betina PBKo dibandingkan dengan penggunaan campuran senyawa etanol dan metanol (Dufour \& Frerot, 2008). Ketertarikan imago betina PBKo dan penggerek cabang (Xylosandrus compactus) terhadap ekstrak buah kopi yang telah matang lebih besar dibandingkan ekstrak buah kopi yang belum matang maupun buah kopi yang kering di pohon (Giordanengo et al., 1993).

Ekstrak bagian tanaman kopi juga dapat digunakan sebagai atraktan dalam mengendalikan hama tanaman kakao. Ekstrak biji kopi dengan konsentrasi 5\% dan 7\% mampu menarik imago Conomophora cramerella dibandingkan dengan ekstrak kulit buah kakao. Pemanfaatan ekstrak daun kopi dengan konsentrasi 5\% sebagai senyawa atraktan juga mampu menarik imago $C$. cramerella (Firmansyah dkk., 2012). Buah kopi Arabika juga menghasilkan senyawa kimia yang komponennya menyerupai senyawa sex pheromone dari jenis serangga Scolytidae (Jaramillo et al., 2013). Kandungan senyawa asam klorogenat pada ekstrak kulit buah kopi (eksokarp) ternyata mampu menarik 
H. hampei (Jaramillo et al., 2006; Firmansyah dkk., 2012).

Hingga saat ini, penelitian mengenai air sulingan beberapa bagian tanaman kopi terhadap hama PBKo belum banyak dilakukan. Dengan demikian, penelitian ini bertujuan untuk mengetahui potensi air sulingan beberapa bagian tanaman kopi sebagai atraktan dalam mengendalikan hama PBKo.

\section{METODE PENELITIAN}

Penelitian ini telah dilaksanakan pada bulan Februari hingga Juli 2015 yang bertempat di Laboratorium Entomologi, Departemen Hama dan Penyakit Tumbuhan, Fakultas Pertanian, Universitas Padjadjaran. Metode yang digunakan dalam penelitian ini adalah eksperimental dengan Rancangan Acak Kelompok (RAK). Perlakuan yang digunakan pada penelitian ini adalah air sulingan beberapa bagian tanaman kopi, yakni buah, biji, cabang atau ranting, dan daun yang masing-masing diulang sebanyak lima kali.

Bagian tanaman kopi diperoleh dari Perkebunan Kopi Rakyat Rancakalong, Kabupaten Sumedang. sebanyak $20 \mathrm{~kg}$ dicacah dan dikeringanginkan selama 3 hari. di atas lembaran kertas koran untuk mengurangi kadar airnya hingga $15 \%$. Bahan sulingan dibawa ke laboratorium untuk disuling dengan cara distilasi uap air, sehingga dihasilkan air sulingan bagian tanaman kopi yang diuji potensinya sebagai atraktan bagi PBKo. Dengan metode distilasi uap, bahan tanaman tidak mengalami kontak langsung dengan air mendidih, karena terpisah antara bahan yang disuling dengan air penghasil uap.

Bahan yang akan disuling ditempatkan di atas saringan. Air yang ditempatkan pada ketel lainnya dididihkan, dan uap jernih yang bertekanan tinggi dialirkan melalui pipa dari ketel ke dalam alat penyuling. Bersama uap air, minyak atsiri dari kulit ranting dan daun tanaman kopi ikut terbawa. Selanjutnya campuran minyak dan uap air dikondensasi di pipa pendingin. Setelah mengalami pendinginan, campuran minyak dan air ditampung di bejana pemisah.

Hewan uji berupa imago betina PBKo diperbanyak di Laboratorium Perbanyakan, Departemen Hama dan Penyakit Tumbuhan, Fakultas Pertanian, Universitas Padjadjaran. Wadah yang digunakan untuk perbanyakan adalah toples yang permukaan atasnya diberi lubang yang ditutupi kain kasa.
Pakan yang digunakan untuk serangga PBK ini adalah buah kopi arabika yang masih segar sebanyak lima buah yang dimasukkan ke dalam toples. Waktu yang diperlukan untuk perbanyakkan selama 55 hari.

Alat yang digunakan untuk mengetahui ketertarikan serangga PBK adalah olfaktometer modifikasi. Alat olfaktometer didesain sesuai dengan jumlah perlakuan yang diujikan. Toples plastik berbentuk silinder dengan diameter $30 \mathrm{~cm}$ dan tingginya $30 \mathrm{~cm}$ menjadi tempat awal serangga PBK diinfestasikan. Di sekeliling toples dibuat lima lubang dengan diameter $2,5 \mathrm{~cm}$ dengan jarak masing-masing lubang $3,5 \mathrm{~cm}$. Pada lubang kemudian dipasang tabung plastik kecil yang mengarah keluar, sepanjang $30 \mathrm{~cm}$. Di bagian dasar tabung dibuat lubang sebagai tempat sirkulasi udara. Lubang tersebut dilapisi kain kasa agar serangga tidak keluar. Olfaktometer yang akan didesain sebanyak 15 buah. Masing-masing olfaktometer berisi lima perlakuan dengan volume tertentu.

Parameter yang akan diamati dalam penelitian ini adalah banyaknya serangga PBK yang tertarik pada perlakuan yang diujikan. Untuk mengetahui waktu efektif dari air sulingan beberapa bagian tanaman kopi, maka parameter yang dapat diamati adalah waktu yang diperlukan oleh serangga untuk tertarik pada senyawa yang dikeluarkan oleh air sulingan tersebut. Dengan demikian, ditentukan waktu pengamatan selama 4 hari, yang dimulai dari 2 jam, 4 jam, 8 jam, 24 jam, 48 jam, 72 jam dan 96 jam. Selama pengamatan, diamati pula perilaku serangga selama tiga waktu pengamatan, yaitu 2 jam, 4 jam dan 8 jam pengamatan setelah perlakuan dipasang.

Data yang diperoleh diolah dengan menggunakan analisis sidik ragam yang akan dilanjutkan dengan uji lanjut Uji Jarak Berganda Duncan dengan taraf kepercayaan 5\%. Analisis statistik menggunakan software SPSS versi 17.

\section{HASIL DAN PEMBAHASAN}

Potensi air sulingan bagian tanaman kopi sebagai atraktan terhadap imago betina PBKo didasarkan pada hasil pengujian ketertarikan imago betina PBKo dan perilakunya terhadap air sulingan bagian tanaman kopi. Hasil pengujian menunjukkan bahwa air sulingan bagian tanaman kopi berpotensi sebagai atraktan karena mampu menarik imago betina PBKo. Hasil pengujian ketertarikan imago betina PBK terhadap air hasil sulingan bagian tanaman kopi selama 24 jam disajikan pada Tabel 1. 
Tabel 1 menunjukkan bahwa terdapat perbedaan jumlah rata-rata imago betina PBKo yang tertarik pada air sulingan bagian tanaman kopi. Jumlah rata-rata imago betina PBKo yang paling banyak tertarik adalah pada air hasil sulingan biji kopi (P2) yaitu sebanyak 8,8 ekor. Tabel 1 juga menunjukkan bahwa sejumlah imago betina PBKo juga memiliki ketertarikan kepada air sulingan kulit buah, tetapi tidak berbeda nyata secara statistik dengan Kontrol. Perlakuan P3 dan P4 keduanya juga tidak berbeda nyata dengan kontrol (P0).

Tabel 1. Rata-rata jumlah imago betina PBKo terhadap air sulingan beberapa bagian tanaman kopi.

\begin{tabular}{lc}
\hline \multicolumn{1}{c}{ Perlakuan } & Jumlah Rata-Rata Tangkapan (ekor) \\
\hline P0 (tanpa air sulingan) & $0,2 \mathrm{a}$ \\
P1 (air sulingan kulit buah kopi) & $4,0 \mathrm{~b}$ \\
P2 (air sulingan biji kopi) & $8,8 \mathrm{c}$ \\
P3 (air sulingan daun kopi) & $2,2 \mathrm{ab}$ \\
P4 (air sulingan ranting kopi) & $2,2 \mathrm{ab}$ \\
\hline
\end{tabular}

${ }^{*}$ Kolom yang diikuti huruf yang sama tidak berbeda nyata pada uji lanjut Duncan dengan taraf nyata $5 \%$.

Air hasil sulingan biji kopi merupakan perlakuan terbaik dalam menarik imago betina PBKo dibandingkan perlakuan lainnya. Hal ini sesuai dengan percobaan yang dilakukan oleh Prokopy et al. (1997) bahwa kemampuan senyawa volatil dari ekstrak kasar biji kopi Arabika matang mampu menarik imago betina PBKo maupun lalat buah Mediterranean dibandingkan ekstrak kasar kulit buah, daun dan ranting kopi.

Keunggulan senyawa volatil biji kopi dalam menarik imago betina PBKo juga dibuktikan oleh percobaan yang dilakukan Martinez \& Ondarza (1996) yang mengungkapkan ekstrak methylene chloride biji kopi matang merupakan perlakuan terbaik dalam menarik imago betina PBKo. Jumlah tangkapan yang dihasilkan yaitu 30,05 ekor lebih banyak dibandingkan ekstrak methylene chloride daun (8,55 ekor), ranting (18,02 ekor), batang (17,09 ekor), bunga $(4,78)$ ekor dan kulit buah kopi matang (17,12 ekor).

Hasil analisis senyawa volatil yang dihasilkan biji kopi Arabika matang diantaranya methylcyclohexane, ethylbenzene, nonane, 3-ethyl4-methyl pentanol dan limonene secara aktif menarik imago betina PBKo. Kombinasi dari berbagai senyawa volatil tersebut memberikan respon yang signifikan terhadap jumlah ketertarikan imago betina PBKo (Mendesil et al., 2009). Senyawa volatil yang dihasilkan biji kopi matang bersifat sebagai kairomon yang menarik imago betina PBKo dalam meletakkan telur (Prokopy et al., 1997).

Keaktifan senyawa volatil dapat bekerja secara spesifik dari suatu jenis senyawa maupun kombinasi beberapa senyawa volatil. Faktor lain yang mempengaruhi perbedaan hasil jumlah tangkapan imago yaitu banyaknya komponen dan tingkat konsentrasi senyawa volatil yang terkandung dari tiap bagian tanaman (Mendesil et al., 2009).

Jumlah dan jenis senyawa volatil dari tiap bagian tanaman berhubungan dengan banyaknya rendemen minyak atsiri yang terkandung dalam tanaman. Kandungan minyak atsiri pada bagian tanaman kopi diduga sedikit dan masih belum diketahui kadar rendemennya. Hasil pengujian menunjukkan bahwa air hasil sulingan biji kopi mampu menarik imago betina PBKo sehingga potensi tersebut dapat dimanfaatkan sebagai atraktan alternatif dalam pengendalian hama PBKo.

Air sulingan bagian tanaman kopi juga memengaruhi perilaku imago betina PBKo. Persentase perilaku atau keaktifan gerak imago betina PBKo yang dipengaruhi air sulingan disajikan pada Tabel 2. Perilaku imago betina PBKo yang terdapat pada gelas perlakuan selama pengujian sebagian besar bergerak aktif dibandingkan bergerak perlahan, diam dan mati. Air hasil sulingan juga tidak menyebabkan mortalitas maupun pengaruh yang menghambat aktivitas serangga.

Salah satu faktor yang mempengaruhi keadaan imago betina PBKo selama pengujian yaitu volume uji air sulingan yang digunakan. Penggunaan volume uji air hasil sulingan sebesar $4 \mathrm{ml}$ pada kulit buah dan $2 \mathrm{ml}$ pada daun dan ranting tidak bersifat fumigan maupun menghambat aktivitas imago betina PBKo dalam mendekati setiap perlakuan. Hal ini bisa dilihat dari jumlah imago betina PBKo bergerak aktif lebih banyak dibandingkan bergerak perlahan maupun diam yang terdapat pada semua perlakuan. 
Tabel 2. Persentase keadaan imago betina PBKo dalam 24 jam terhadap air sulingan beberapa bagian tanaman kopi.

\begin{tabular}{lcccc}
\hline \multirow{2}{*}{ Perlakuan } & \multicolumn{3}{c}{ Persentase Keadaan Imago Betina PBKo (\%) } \\
\cline { 2 - 5 } & Bergerak Aktif & $\begin{array}{c}\text { Bergerak } \\
\text { Perlahan }\end{array}$ & Diam & Mati \\
\hline P0 (tanpa air sulingan) & 2,28 & 0 & 0 & 0 \\
P1 (air sulingan kulit buah kopi) & 34,09 & 11,36 & 0 & 0 \\
P2 (air sulingan biji kopi) & 86,36 & 11,36 & 2,28 & 0 \\
P3 (air sulingan daun kopi) & 20,45 & 2,28 & 2,28 & 0 \\
P4 (air sulingan ranting kopi) & 18,18 & 4,54 & 2,28 & 0 \\
\hline
\end{tabular}

Pengujian ketahanan air hasil sulingan dilakukan untuk mengetahui seberapa lamanya kemampuan tiap perlakuan mampu menarik imago betina PBKo. Kemampuan dari berbagai air hasil sulingan dalam menarik imago betina PBKo selama 9 hari waktu pengamatan disajikan pada Gambar 1. Hasil pengujian menunjukkan terdapat fluktuasi jumlah tangkapan. Kemampuan terbaik dari seluruh air hasil sulingan dalam menangkap imago betina PBKo yaitu pada pengamatan hari ke-3. Hal ini bisa dilihat dari puncak jumlah tangkapan imago betina PBKo untuk semua perlakuan dalam 9 hari waktu pengamatan.

Penurunan jumlah tangkapan terjadi pada hari ke-5 hingga ke-7, kecuali pada P1 yang kembali mengalami peningkatan jumlah tangkapan di hari ke-7. Selanjutnya pengamatan di hari ke-9 pada P2, P3 dan P4 kembali mengalami peningkatan jumlah tangkapan kecuali pada P1. Namun demikian, peningkatan jumlah tangkapan yang terjadi pada ketiga perlakuan tersebut tidak sebesar saat pengamatan di hari ke-3.

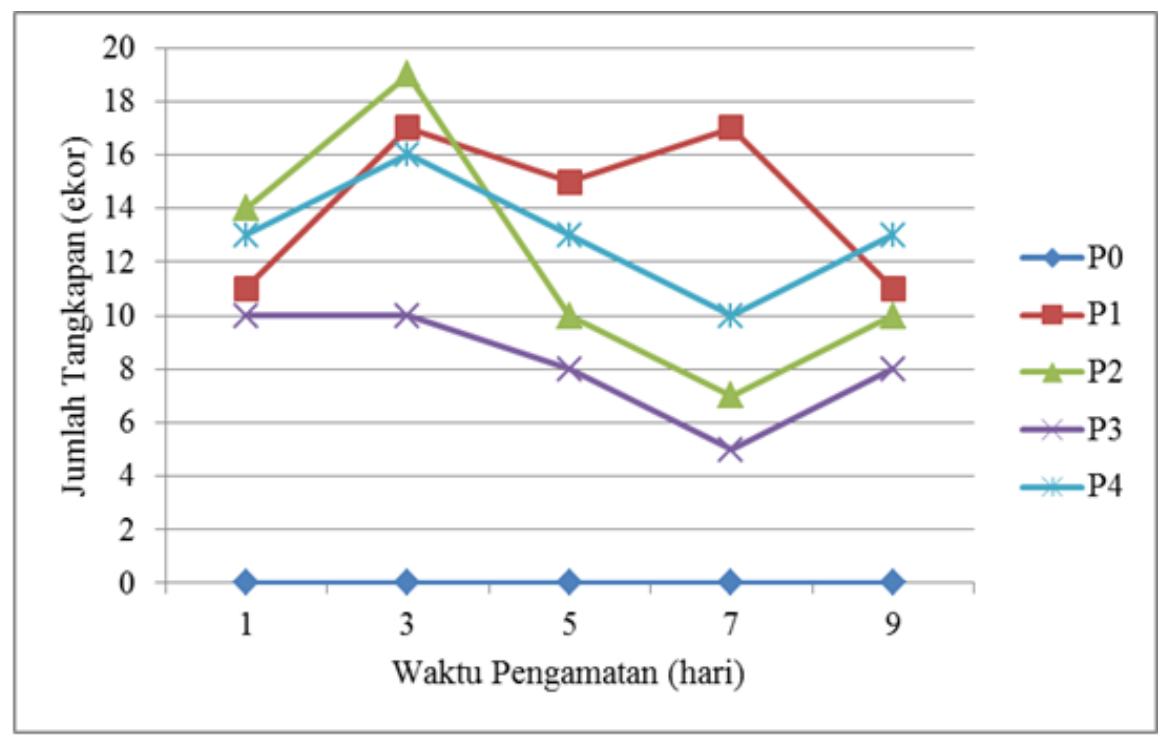

Gambar 1. Ketahanan air hasil sulingan bagian tanaman kopi dalam menarik imago betina PBKo. $\mathrm{P} 0=$ tanpa air sulingan, $\mathrm{P} 1=$ air sulingan kulit buah kopi, $\mathrm{P} 2=$ air sulingan biji kopi, $\mathrm{P} 3=\mathrm{air}$ sulingan daun kopi, dan $\mathrm{P} 4=$ air sulingan ranting kopi.

Hasil pengujian menunjukkan bahwa kemampuan terbaik yang ditunjukkan dari semua perlakuan air hasil sulingan terjadi di hari ke-3 waktu pengamatan. Peningkatan jumlah tangkapan dari hari ke-1 menuju hari ke-3 disebabkan karena banyaknya senyawa volatil dari setiap perlakuan air hasil sulingan yang sudah mulai menguap dan memenuhi ruang di dalam gelas perlakuan. Keadaan tersebut akhirnya mempengaruhi peningkatan 
jumlah tangkapan imago betina PBKo secara signifikan dari setiap perlakuan.

Terjadinya penurunan jumlah tangkapan imago betina PBKo pada hari ke-5 hingga hari ke-7 di setiap waktu pengamatan disebabkan karena jumlah senyawa volatil air hasil sulingan yang berada di dalam gelas perlakuan dimungkinkan sudah mulai berkurang. Hal tersebut juga didukung dengan peningkatan suhu di dalam laboratorium di hari ke-5 hingga hari ke-7 yang berkisar $25,5-27,9^{\circ} \mathrm{C}$ hingga $25,8-27,9^{\circ} \mathrm{C}$ yang mempercepat proses penguapan senyawa volatil (Lampiran 3). Menurut Salbiah dkk. (2013) peningkatan suhu ruang lebih dari $25^{\circ} \mathrm{C}$ menyebabkan masa aktif atraktan akan semakin cepat berakhir. Namun demikian, hal tersebut tidak terjadi pada perlakuan air hasil sulingan kulit buah kopi (P1) yang justru mengalami peningkatan jumlah tangkapan.

Peningkatan jumlah tangkapan imago betina PBKo di hari ke-9 kembali terjadi pada perlakuan air hasil sulingan biji (P2), daun (P3) dan ranting (P4). Hal tersebut dimungkinkan karena masih adanya sisa dari senyawa volatil yang bertahan dari masing-masing perlakuan sehingga potensi untuk menarik imago betina PBKo masih mungkin terjadi. Keadaan tersebut juga didukung dengan penurunan suhu di dalam laboratorium menjadi $24,8-27,2^{\circ} \mathrm{C}$ sehingga masa aktif dari sisa senyawa volatil air hasil sulingan dapat bertahan untuk beberapa saat. Meskipun demikian, peningkatan jumlah tangkapan imago betina PBKo yang terjadi pada ketiga perlakuan tersebut tidak sebesar jumlah tangkapan di hari ke-3.

Faktor peningkatan dan penurunan suhu pada saat pengujian mempengaruhi fluktuasi jumlah tangkapan serangga. Semakin rendah suhu maka masa bertahan senyawa volatil atraktan akan semakin lama dan begitu juga sebaliknya semakin tinggi suhu maka masa aktif senyawa volatil atraktan akan semakin cepat berakhir (Salbiah dkk., 2013). Hal tersebut tentunya berpengaruh pada kemampuan senyawa volatil untuk menguap yang pada akhirnya akan mempengaruhi jumlah tangkapan serangga. Pengaruh suhu juga akan menentukan aplikasi atraktan di beberapa tempat dengan beragam ketinggian. Semakin tinggi tempat maka masa aktif atraktan akan semakin lama dan begitu juga sebaliknya (Efendy dkk., 2010).

Kemampuan air hasil sulingan sangat berhubungan dengan kadar minyak atsiri yang terkandung pada tiap bagian tanaman. Air hasil sulingan memiliki kandungan minyak atsiri yang rendah sehingga jangka waktu senyawa volatil untuk menarik kehadiran serangga menjadi lebih pendek. Penelitian yang dilakukan oleh Kardinan dkk. (2009) menunjukkan air hasil sulingan dari tanaman selasih yang mengandung metil eugenol sebesar $0,46 \%$ hanya mampu bertahan dalam menangkap lalat buah selama satu minggu. Jangka waktu tersebut lebih rendah dibandingkan penggunaan minyak atsiri selasih yang mengandung eugenol sebesar $77,9 \%$ yang mampu menangkap lalat buah selama 1 bulan lamanya.

Keefektifan air hasil sulingan dari masingmasing bagian tanaman kopi dalam menarik imago betina PBKo hanya mampu bertahan selama 3 hari. Kandungan minyak atsiri dalam air hasil sulingan yang rendah serta pengaruh dari fluktuasi suhu mempengaruhi jumlah tangkapan imago betina PBKo. Berdasarkan hal tersebut maka penerapan air hasil sulingan bagian tanaman kopi dalam pemakaiannya di lapangan memerlukan aplikasi berulang setiap 3 hari sekali.

\section{SIMPULAN}

Air sulingan bagian tanaman kopi berpotensi sebagai atraktan terhadap hama PBKo. Rata-rata jumlah imago betina PBKo terbanyak yang tertarik yaitu pada air sulingan biji kopi sebanyak 8,8 ekor. Masa aktif dari semua air sulingan yang berperan sebagai atraktan dalam menarik imago betina PBKo yaitu selama 3 hari.

\section{UCAPAN TERIMA KASIH}

Penelitian ini terlaksana berkat bantuan dana dari Program Hibah Kompetisi Penelitian Fakultas Pertanian, Universitas Padjadjaran.

\section{DAFTAR PUSTAKA}

Asosiasi Eksportir dan Industri Kopi Indonesia (AEKI). 2014a. Perkembangan Luas Areal dan Produksi Perkebunan Kopi di Indonesia Menurut Pengusahaan Tahun 1996-2014. Direktorat Jenderal Perkebunan Kementerian Pertanian.

Asosiasi Eksportir dan Industri Kopi Indonesia (AEKI). 2014b. Sejarah Kopi di Indonesia. Dikutip dari http://www.aekiaice.org/page/sejarah/id. Diakses pada tanggal 15 Januari 2015.

Biro Pusat Statistik (BPS). 2013. Produksi Perkebunan Rakyat Menurut Jenis Tanaman (2000-2013). Dikutip dari 
www.bps.go.id. Pada tanggal 31 Januari 2015.

Damon, A. 2000. A review of the biology and control of the coffee berry borer, Hypothenemus hampei (Coleoptera: Scolytidae). Review Article. Bulletin of Entomological Research. (90): 453-465.

Dufour, B. P., B. Frerot. 2008. Optimization of coffee berry borer, Hypothenemus hampei Ferrari (Col., Scolytidae), mass trapping with an attractant mixture. J. Appl. Ent. (132): 591600. Blackwell Verlag.

Durham, S. 2004. Stopping The Coffee Berry Borer From Borer Into Profit. http://agris.fao.org/agrissearch/search.do?recordID=US20130096482 7. Pada tanggal 31 Januari 2015.

Efendy, T. A., R. Rani, S. Samad. 2010. Pengujian beberapa jenis tanaman sebagai sumber atraktan lalat buah (Bactrocera spp.) (Diptera: Tephridae) pada tanaman cabai (Capsicum annum L.). Prosiding Seminar Nasional. Universitas Sriwijaya.

Ermawati, Rr., R. W. Arief, Slameto. 2008. Teknologi Budidaya Kopi Poliklonal. Badan Penelitian dan Pengembangan Pertanian. Seri Buku Inovasi. ISBN: 978-979-1415-354.

Firmansyah, A. M., S. Sjam, V. S. Dewi. 2012. Ekstrak biji kopi sebagai atraktan imago penggerek buah kakao (Conomophora cramerella Snellen). Fakultas Pertanian Universitas Hasanuddin.

Giordanengo, P., L. O. Brun, B. Frerot. 1993. Evidence for allelochemical attraction of the coffee berry borer, Hypothenemus hampei, by coffee berries. Journal of Chemical Ecology. 19 (4): 763-771.

Izhar, N., Yardha. 2001. Teknologi Budidaya Kopi Arabika. Badan Penelitian dan Pengembangan Pertanian. Jambi.

Jaramillo, J., C. Borgemeister, P. Baker. 2006. Coffee berry borer Hypothenemus hampei (Coleoptera: Curculionidae): searching for sustainable control strategies. Bulletin of Entomological Research. 6 (96): 223-233.

Jaramillo, J., A. C. Olaye, H. M. Poehling, C. Kamonjo, C. Borgemeister. 2009. Development of an improved laboratory production technique for the coffee berry borer Hypothenemus hampei, using fresh coffee berries. Journal Compilation
Entomologia Experimentalis et Applicana. (130): 275-281.

Jaramillo, J., B. Torto, D. Mwenda, A. Troeger, C. Borgemeister, H.M. Poehling, W. Francke. 2013. Coffee berry borer joins bark beetles in coffee clatch. Journal Plos One. 8 (9).

Kardinan, A. 2011. Penggunaan pestisida alami sebagai kearifan lokal dalam pengendalian hama tanaman menuju sistem pertanian organik. Pengembangan Inovasi Pertanian. 4 (4): 262-278.

Kementerian Perdagangan Republik Indonesia. 2014. Ekspor Kopi Ditargeetkan Capai 9,5\%. Siaran Pers. Dikutip dari http://www.kemendag.go.id/id/news/2014/1 1/22/ekspor-kopi-ditargetkan-capai-95. Pada tanggal 31Januari 2015.

Kustiari, R. 2007. Perkembangan pasar kopi dunia dan implikasinya bagi Indonesia. Forum Penelitian Agro Ekonomi. 25 (1): 43-55.

Lima, D. H. U., M. U. Ventura, A. Y. Mikami, F. C. Silva, L. Morales. 2010. Ecology, Behavior and Bionomics: Responses of coffee berry borer, Hypothenemus hampei (Ferrari) (Coleoptera: Scolytidae), to vertical distribution of methanol. Neotropical Entomology. 39 (6): 930-933.

Mendesil, E., T. J. A. Bruce, C. M. Woodcock, J. C. Caulfield, E. Seyoum, J. A. Pickett. 2009. Semiochemical used in host location by the coffee berry borer, Hypothenemus hampei. Journal of Chemical Ecology. (35): 944-950.

Prokopy, R. J., T. W. Phillips, R. I. Vargas, E. B. Jang. 1997. Defining sources of coffee plant odor attractive to Ceratitis capitata flies. Journal of Chemical Ecology. 23 (6): 15771587.

Salbiah, D., A. Sutikno, A. Rangkuti. 2013. Uji beberapa minyak atsiri sebagai atraktan lalat buah pada tanaman cabai merah (Capsicum annum L.). Jurnal Agroteknologi. 4 (1): 1318.

Solikhin. 1997. Ketertarikan walang sangit (Leptocorisa oratorius F.) terhadap beberapa bahan organik yang membusuk. Jurnal Hama dan Penyakit Tumbuhan Tropika. 7 (1): 10-24.

Susilo, A. W. 2008. Ketahanan tanaman kopi (Coffea spp.) terhadap hama penggerek buah kopi (Hypothenemus hampei Ferr.). Review Penelitian Kopi dan Kakao. 24 (1): 1-14. 
Wiryadiputra, S. Keefektifan insektisida cyantraniliprole terhadap hama penggerek buah kopi (Hypothenemus hampei) pada kopi arabika. Pelita Perkebunan. 28 (2): 100-110. 
